\title{
The Future of Instruction Media in Indonesian Education: Systematic Review
}

\author{
Sudarmo ${ }^{1}$, Ardian Arifin², Petrus Jacob Pattiasina3, Vani Wirawan4, Aslan5 \\ DOI: $10.35445 /$ alishlah.v13i2.542
}

Article Info

Keywords:

Print Media;

Digital Media;

Indonesian Education;

International

Publications

Kata kunci:

Media Cetak;

Media Digital;

Pendidikan Indonesia;

Publikasi Internasional

\section{Abstract}

This study aimed to answer whether digital devices replace print media in education in Indonesia's digital era. Systematic studies and experts' findings can get a basic understanding of print media that can be replaced by digital media in education today and in the future. For this reason, the researchers have attempted to collect literature and publications related to this theme. Then it analyzes critically to prove whether our hypothesis is accepted or rejected. For example, the way we research seeks to understand the question's theme and matches the findings of several publications that we target from 2010 to 2020. Data sources come from Google Scholar, ERIC publications, and other search engines. This analytical process involves coding systems, content evaluation, indepth interpretation, and concluding to obtain findings characterized by validity and trustworthiness. The results reveal that slowly the role of electronic media has begun to take over paper media. However, with the condition of Indonesian education in general, the role of print media continues to dominate the world of Indonesian education today, especially in remote areas of the country where modern educational facilities are not yet supported. Therefore, this finding is useful for policymakers and further study in a similar field.

\begin{abstract}
Abstrak
Penelitian ini bertujuan untuk menjawab pertanyaan apakah perangkat digital menggantikan media cetak di bidang pendidikan di era digital Indonesia saat ini. Tujuannya, melalui kajian sistematis, temuan para ahli, peneliti bisa mendapatkan pemahaman mendasar tentang media cetak yang bisa tergantikan oleh kehadiran media digital dalam pendidikan saat ini dan di masa yang akan datang. Untuk itu, peneliti berupaya mengumpulkan literatur dan publikasi yang berkaitan dengan tema ini. Kemudian menganalisis secara kritis untuk membuktikan apakah hipotesis diterima atau ditolak. Misalnya, cara meneliti, mencari pemahaman tentang tema pertanyaan dan mencocokkannya dengan temuan dari beberapa publikasi yang kami targetkan dari tahun 2010 hingga 2020. Sumber datanya berasal dari Google Scholar, publikasi ERIC, dan mesin pencari lainnya. Proses analisis melibatkan sistem pengkodean, evaluasi konten, penafsiran mendalam dan ambil kesimpulan untuk mendapatkan temuan yang ditandai dengan validitas dan kepercayaan. Hasilnya mengungkapkan bahwa perlahan-lahan peran
\end{abstract}

\footnotetext{
${ }^{1}$ Sekolah Tinggi Ilmu Ekonomi Balikpapan, Indonesia

Email: sudarmo@stiebalikpapan.ac.id

2 IKIP PGRI Pontianak, Indonesia

Email: Ardian.arifin@yahoo.com

3 Universitas Pattimura, Indonesia

Email: pattiasinaethus@gmail.com

4 Universitas Diponegoro, Indonesia

Email: vaniwirawan@gmail.com

5 Institut Agama Islam Sultan Muhammad Syafiuddin Sambas, Indonesia

Coresponding author email: aslan@iaisambas.ac.id
}

Received: May 5, 2021; Received in revised form: August 19 2021; Accepted: August 25, 2021; Available online: August 31, 2021

This is an open access article under a Creative Commons Attribution-NonCommercial-ShareAlike 4.0 International License. 
media elektronik mulai mengambil alih peran media kertas. Meski demikian, dengan kondisi pendidikan Indonesia secara umum, peran media cetak terus mendominasi dunia pendidikan Indonesia saat ini terutama di pelosok tanah air yang belum didukung sarana pendidikan modern.

\section{INTRODUCTION}

Whether printed or electronic, any media is created as a communication tool for humans. (Schivinski \& Dabrowski, 2016; Watson \& Hill, 2015; Aslan, 2019; Putra \& Aslan, 2020; Putra et al., 2020). The creation of the media facilitates communication, both oral and written. As a differentiator between the two types of media, print media is a device used as an intermediary to inform a matter or problem to the public in printed form. Meanwhile, digital media is a content format that digital devices can access. This digital media can be in websites, social media, digital images and videos, digital audio. Because communication delivers messages from one individual to another, communication requires media or intermediaries. Technically, of course, there is a difference between print media and digital media. However, speaking of goals and principles, both have one goal: a practical and efficient means of communicating. Because people in every era always tend to look for practical and cheap formats, they face changes according to the times' demands. Because the changes and demands of the times have helped change human behavior in accepting a communication device. Likewise, in the context of education, in order to provide valuable educational services, humans must decide whether to continue using printed or electronic media. (Nicholas \& Paatsch, 2018). For that, we have tried to study it through various ways and efforts.

The part of print media today in the instructive climate stays potential; as a device to explain the messages introduced in the homeroom climate among instructors and understudies and understudies and different understudies. Explain the message with the goal that it is not excessively expressed. It conquers the room's limits, time, energy, and faculties, making an enthusiasm for learning, direct communication among understudies, and learning assets. There is no uncertainty about the presence of print media in the realm of learning study halls. Its existence Tas a delivery of uniform educational content. Because the learning process becomes more precise and more enjoyable, the educational process becomes more interactive, efficient, and practical. Besides that, the existence of printed media can improve the quality of learning outcomes. It allows the learning process to be carried out anywhere and anytime without being tied to other supporting factors such as electrical power and internet connectivity access. (Mason \& Hajek, 2020).

According to Mason \& Hajek (2020), print media in learning are various media to convey learning messages in which the supporting text and illustrations are contained. Suppose the text is printed on hardcopy and used for learning. In this case, the print media can be the spread of print technology with the advantages of conveying various information related to facts and abstract concepts: knowledge, skills, or attitudes. Besides the advantages of its usefulness, print media is also straightforward to use anytime and anywhere. Easy to use, independent of other equipment. The sleek and small general print media packaging allows students to carry it wherever they go smoothly. In addition to its physical form, Hamid \& Jahan (2015) print media is also easy to carry, the arrangement or presentation of the material is easy to learn. For example, presentation techniques such as index writers can present an unlimited amount of information. According to need, interest, information presentation can be studied more interesting because it is equipped with pictures.

On the other hand, Firmstone \& Coleman (2015) observed the miracle of utilizing web-based media as online digital media has multiplied in this decade. Students as the millennial generation or native computerization are the primary users in web-based digital media today. On the other hand, exploration of computers' computerized capabilities is still rarely carried out, especially in Indonesia's regions. A study selects the subject of children aged 17-21 years who are web-based digital media users. The findings made in other research indicate the importance of advanced digital literacy skills programs that are firmly tied to digital information. Finally, it became increasingly 
aware that this digital media program gave a massive commitment to data dissemination in extensive communication to set aside print media.

Moreover, online media is very popular with young people, so there is a tendency to forget about using print media. Likewise, in education at a high level, almost all participants have personal digital devices and the talent to adapt to this technology. (Kukulska-Hulme, 2012). Therefore, with this expertise, the current generation of education no longer needs the skills to use increasingly unreliable print media to accelerate millennial generation education. With this trend, it can be ascertained that media users' tendency to leave the print media, which was the mainstay of the previous generation when local conditions were not yet advanced in the digital media world.

The improvement of online media is presently a danger to papers and print media. The web's fast improvement has urged individuals to get to online media effectively through cellphone or contraptions. Print media is in danger; steadfast perusers of print media will probably go to online media. The truth compromises print media distributors, yet print media has a particular character specifically: clear, total, and itemized news; other than that, for quite a long time, the print media has gone with the improvement of human development, so it is not handily failed to remember. Media online is quick, modern, and consistent, yet this news must be gotten to by utilizing modern apparatuses, and not all individuals have these instruments and get innovation. Be that as it may, the print media have made early expectations make online media to help distributed print media.

Andoko (2010), in his investigation composed, when the cost of paper was getting more costly, the print media industry is getting progressively hard to endure, the decision for print media is inescapable need to need to change themselves to take an interest in the improvement of computerized innovation as of now, is and will happen a lot further. At this point, Kompas paper is not in a position as just a paper in the printed sense yet as a data supplier media with different stages, for example, web, portable and advanced gadgets. As a stage, print media may one day vanish. However, as a data medium, it will last, even with more extravagant substance. Nonetheless, papers' difficulties are more troublesome than books since the paper plan of action depends more on income from publicizing. The worldview of getting data through the web is free is inconvenient for paper administrators to gather charges from clients. From one perspective, advanced advancement innovation has subverted the mastery of data by a tip-top gathering and opened up openings for the local area to take an interest. Then again, advanced innovation will save the education progress while saving the climate.

A few intellectuals had anticipated the destruction of print media. Supadiyanto (2013) composed various world figures who have anticipated the rise of innovation paperless paper. These figures are Roger F. Fidler, Bill Entryways, Rupert Murdoch, and Philip Meyer. There are four ramifications of the expanding pervasiveness of tablet or paperless utilization in Indonesia's broad communications industry. The immediate ramifications are a significant innovation move from print media to business-based paperless papers that are modest regardless of creation expenses and appropriation worldwide. Second, other immediate ramifications are an adjustment in the direction and way of life of the internal local area getting too broad communications from the earliest starting point, which was as yet customary, by opening sheet by the sheet; change to squeezing a catch or tapping the screen.

Observing the world's current state in the digital and pandemic era, it seems enough to understand every education manager starting with government and society. This era is known as an era without borders and zones. Everything will become more instant and cash. Beniger (2009) also argues that the digital era has become an era of controlling the revolution in times and civilization where technology and economics control all sectors known as the information society. As a simple example, students can easily find information through internet networks to complete their school homework. However, it does not include specific conditions in areas known as the frontier, 
outermost, left behind. Technology will be beneficial for schools' outermost and underdeveloped category because teachers' presence has become an everyday issue for no solution (Skinner, 2016).

In the later technological era, most of the population is a new generation who will change their old habits to new civilizations that tend to be instances and practical Morganti et al., 2019). So, the development of the digital world is so dynamic that gradually it affects and changes people's lifestyles without being able to be avoided by anyone. In particular, the world of education has also changed, for example, the acceptance model for tools that tends to be practical and efficient. They will be susceptible to efficiency and productivity. Koomey et al. (2010) looked at the implications of civilization trends in efficiency with computing systems. So that progress does not wait a century to experience the ever-changing digital era. Students now, when they grow up, will face the digitization of life. Cameron (2017) questioned if the Robots Take Your Job: It is estimated that new types of currently unimaginable jobs will replace $65 \%$ of current jobs. For example, the presence of robots and projector equipment is applied to computers and cellphones. Various projector factories and even televisions will soon close, visitors to the folk entertainment stage like in the past will disappear. Many policymakers and educational interests, both bureaucrats, community leaders, and parents, are concerned about the negative impact of using cell phones on children. Many schools also prohibit their students from carrying cell phones. There is concern returning to the past or continuing to advance with the discovery of media technology is ready to leave the old ways like the era of printed media.

Digital innovation in modern education. According to Mondal (2020), one of the most remarkable innovations is digital innovation in management education. Digital innovations for customer engagement, management, and organizational improvement are that digital technology can provide solutions to public problems, namely changes in education for the younger generation. If technology has answered the problem, the wider community will enjoy good educational services cheaply and productively. As a result, it will be easy for people to get a more comfortable and cheaper education. Besides, many teachers whose teaching abilities are questionable will be assisted by technology as it is indicated that more than half of them do not pass the teacher competency test. As a result, many Indonesian children will get better quality teaching and education. As a result, the ability to read, count, and teach Indonesian children is not far behind Singapore, Vietnam, Malaysia, and Thailand based on the PISA test Darmawan, (2020). So that Indonesia deserves to collaborate with which parties, for example, a company based digital technology, Ruangguru, seeks to solve education problems in Indonesia by providing a learning platform via mobile devices. Indonesia has 3.1 million permanent teachers plus more than 800 thousand honorary teachers. About half of this number has sufficient competence to teach with some of the best group teachers who have great potential to become partners of digital learning companies. As a result, old print media technology will slowly be helped by cheap but productive digital technology.

Digital innovation in modern education is ahead in the advanced era; the meaning of education will become an institution where teachers can process student teaching materials with simple media, such as in the old days. (Valli \& Buese, 2007). In the modern era, schools will become laboratories for civilization and change supported by various learning aids in a practical bureaucratic atmosphere. Materials are no longer in traditional forms with paper and blackboard; there will still be times when there will be an era of technological innovation, all midwives in science and change. In other words, in the school of the future, with technological developments, students can study anywhere, and teachers can become facilitators and moderators of learning without being tied to physical space. Ruangguru has shown a little picture of how it can be done. In the future, Indonesia still needs a lot of startup development that offers specialist services, such as digital companies and others to teach students with technology such as in developed countries today that provide reading for students, and the all-digital Pondoksantri, which promoting various madrasah and pesantren lessons with technology adapted to public schools. 
In the future, according to Ternes et al. (2020), the government in many developing countries will facilitate 1000 digital startups' renewal movements to encourage the development and use of technology in providing various innovative solutions. It will be easy and potential to start in educational institutions because the initial changes are easy to make. However, the equal distribution of digital support infrastructure development in all regions is no less important than digital startups' development. For Indonesia to take advantage of digital era technology development, large capacity and superfast internet support in villages and schools are needed. So at that time, print media and the like will slowly be left behind with practical and useful principles.

In line with that, we educational researchers see digital technology innovation to enter the nation's children. (Williamson, 2013). Meanwhile, in other parts, the absorption of technological changes is still low; many say that many educational implementations do not see this as a change. This technological innovation is a change in a new civilization towards the nation's glory. So we identify the problem and try to offer a solution that is still relevant to maintaining print media technology in schools. In other words, what is the fate of schools that still survive on a paper-based? This is a part of the Indonesian education world's powerlessness. After identifying innovative technology such as digital in education and replacing the printed media as a critical problem, we must prove it through in-depth study and study. By reviewing the literature cited by major publications, we will find a solution and make sure it is time for paper-based thinking to change digital learning materials.

\section{METHODS}

This section will describe how research is carried out, especially data collection procedures and other frameworks. First, we explain the purpose of the study, namely an effort to examine dozens of journal articles searching for new insights on whether digital printed is left behind by the arrival of digital media in education in Indonesia. To prove that, we have been involved in literature searches and scientific publications that examine digital technology renovation themes to increase maximum student learning outcomes. The current data focus on the backward range of 15 so that the data is still very valid and accurate. After the data were collected, we examined it by understanding this study's theme and matching it with the publication's sound. If suitable, we continue coding and evaluating to ensure that the publication review's contents and findings have answered this paper's objectives. We rely on current data, and we report it with a qualitative and phenomenological approach so that the data can be said to be valid and trustworthy. All of our procedures and designs are guided by similar studies (McLaughlin et al., 2019; Thomas et al., 2014)

\section{FINDINGS AND DISCUSSION}

The researchers are returning to the core objective of studying innovation technology, especially print media, its fate in the digital media era, and its impact on education. So in this section, we will report on our review of ten published journals specializing in their reports in print and digital media and their impact on Indonesia's implementation of education. Here the report is purely in a descriptive qualitative form. At the same time, the interpretation and critical analysis and the benefits of this paper's findings will be presented in the language section after this section.

Numerous observers and experts have indeed proclaimed that the age of the printed paper is finished. The discoveries of Barthelemy et al. (2011) have put industry-wide turns of events, including falling promoting incomes and divided crowds that are progressively moving on the web, are said to flag the finish of the paper business as we have come to know it. This paper looks to set up how much this portrayal of the paper business' decrease is precisely through a top to bottom writing audit, a progression of talks by specialists in the field, and leading 24 meetings with distributors and editors from six nations. The examination finds that while massive movements occur inside the print business around endeavors to adapt online substance and discover elective wellsprings of income to supplant falling, promoting incomes from print, the business' decay is 
exaggerated. News associations are experiencing an interaction of progress and transformation. Additionally, the paper shows that the story of papers being in interminable decrease is generally Western-driven and does not consider territorial varieties. In many arising nations, print paper deals are strong and developing.

Likewise, the findings of Nossek et al. (2015) mention that the digital media crowd is print kicking the print media. Conditions for using print media in Europe. The dispute over the future elimination of print media is a growing question among scientific partners and specialists. Given that a particular media transfer model or power is essential, this study investigates the crowd by comparing time spent reading print media with those devoted to gobbling up computerized and other media tradeoffs. This study considers nine popularity-based European countries that have undergone highly mechanical changes and represents different societies that can explain differences in usage design. The examination's primary findings show that print media is still an essential part of the new exchange climate among European societies. Recommended goals behind the flexibility of print media over digital media that are tied to auxiliary devices.

Furthermore, the study of Ninghardjanti et al. (2018) states that books and digital facilities question whether this will end the convenience of printed media. This review describes three eBook segments; eBook documents, programming to read eBooks, and gadget equipment to use them. EBooks for students with exceptional needs, eBook benefits, work facilities, and creation facilities are examined. Digital book assets are combined. Finally, this study proves that electronic media's presence has made the convenience of print media slowly fade into media users' hands. This is very pronounced among students, both schools and colleges.

Strouse et al. (2019) prove instructive and fun. This study asks what the parental versus preschool children's insight is and shares the use of computerized and printed media. These questions are intended to survey parental beliefs, inspire and share print media, and facilitate followup with preschool children. They visited 43 guardians and met their children aged 3 to 5 years. The results of this study confirm that their child prefers printouts of sophisticated books and anticipates their child will choose prints from computerized books. Children decide to read computers more often than printed books and choose high-tech gadgets for many purposes. This investigation highlights the differences between how guardians and children perceive media between print and digital media and recommend that guardians further encourage children's use of computerized media by making exposure to advanced media sharing more intuitive.

Twenge et al. (2019) inspected instances of media use among US youth, 1976-2016: The development of electronic media, the rot of TV, and the moving and melting away of print media. The direction of media abilities in the United States is suitably founded on an instructional framework. It shows media preparing procedures, solidifying speculative and general sense, rising plans of constructivist learning hypothesis, media contemplations, and social test rewards. This work has arisen out of shows on print, improvement in coaching throughout the twentieth century, and the ascent of interdisciplinary work in the advanced insightful work association in media studies and mentorship. The core principles of media literacy education in the United States were established by a meeting of analysts and experts in 2007.

Suwana (2017) examines the involvement of Indonesian women in building advanced media capabilities. In Indonesia, there is still a computerized gender partition. Indonesian women need mechanical media education skills to utilize the Internet and improve their skills successfully. Enabling educational capacities combines the ability to use sophisticated media to reach, seek, investigate, reflect, share, and create valuable new things through digital convenience. In this subjective exploratory study, the authors, pioneers, and members of IWITA (Indonesian Women Information Technology Awareness) and FemaleDev (Female Developers) met because this association focuses on creating computerized education for women. Findings show that women's computerized media proficiency remains low due to inadequate educational instruction, the absence of opportunities, and a human-centered framework, especially for women in Indonesia. 
Aditya et al. (2019) examine the challenges of developing virtual learning spaces; however, school students' virtual learning spaces are increasingly not standard. Virtual homeroom here is not the same as professional students in Indonesian universities. Many difficulties and problems come in the implementation of virtual school homeroom. The proposed configuration approach is actualized in the course and assessed with students from two different meetings. Even though the standard of useful plans for virtual learning spaces helped associations overcome difficulties, overcoming standard virtual homeroom plans in professional secondary school education in Indonesia. In general, the study of the proposed approach shows a significant result as a marker of the advantages of using digital technology over printed media.

Supratman \& Wahyudin (2017) understand advanced media capabilities for further education students in Indonesia. They see no mechanical media skills training, which is deemed essential for Indonesia's future severe development. The reason for this research is to reveal the problem in using online media sharply. The results were obtained from 160 students taken by purposive testing ( 81 students in more than five dynamic online media). Since the digital media collaborative learning model was implemented for one full semester in the communication management class for the four classes of third-semester students at school, their view of computerized media capabilities has changed.

Meanwhile, Djiwandono (2017) examines millennial learning styles in higher education utilizing testing in Indonesian academic learning's cultural setting. Investigating the millennial generation's learning styles involved 22 students and succeeded in describing how they handled learning about a subject. Compiled answers are coded to find their favorite style of studying the subject, of course. There is no clear primary relationship between their learning styles and their achievements in language courses and materials. Instead, it was found that there was a subtle relationship between the size of the value reports and their definitive digital capability authority from material alone. However, learning arrangements and social angles are thought to have shaped student learning styles. It means that there is almost no relationship between digital literacy skills and college achievement.

Kilian et al. (2012) successfully examined whether millennials read books or websites. Presenting the typology of web era media The Net generation and the more developed locals all discuss the same thing, talking intensely about miracles, especially in school science. As the requirements recommend, this miracle's fundamental thinking is that younger ages accept new media more than more experienced ages. At any rate, proper investigation is on the media use of the "Internet Generation." Active media use is a fundamental part of social programming and Web 2.0 and may influence the media business. Using an enormous reach observational examination with more than 800 individuals, the makers recognized three distinctive subgroups of Millennials. The outcomes show that even though collaboration and ID with electronic media are significant-high, Millennials are less homogeneous than composing recommendations. Traditional media still examines the fundamental pieces of the media portfolio all in all.

This section will discuss the findings of a review study that aims to gain new insights into the future of instructional media in Indonesia through systematic analysis. We focus on which learning media between print or digital media are relevant and essential when the world of education enters the 21st-century era.

Considering that Indonesia is a developing country, the findings need to be communicated; What is the educational context and which is still relevant to maintaining work-based learning media and the educational conditions in which one must leave paper-based and welcome the arrival of digital media and literacy skills. Based on the previous section's findings, most of the publications we have reviewed emphasize that in the present era in the 21st century, education is slowly trying to switch to digital media for all learning needs. Our findings are also reinforced by Fedorov, (2019) findings, who examined how schools and colleges are now entering the era of audiovisual media. 
Their claims are supported by the views of experts in the fields of international research and education. The same view comes from Collins \& Halverson (2018), who also rethink how education is redesigned in the technological era. They see the digital revolution approaching schools and universities in America and other developing countries like Indonesia.

A study that understands the importance of relevant learning media in the school environment to encourage the best learning outcomes is significant to be informed publicly. So that parties in the world of education get the correct understanding; what type of media should be featured by considering several views of experts in national and international learning technology through a published voice track. We realize that print-based learning media is still superior in Indonesia's educational circles, even though the world is currently offering great digital technology ready to beat paper-based media technology when renovating 21st-century education programs. Rizk (2018) also expressed this view, saying that the 21st-century learning model is a transformative technology in routine, regulation, and educational rituals in the more century. Through his study, another perspective, Selwyn (2020) tells about technology between the presence of technology and the quality of education. Both agreed that the current era was when technology was ready to innovate and renovate education in developed countries and developed countries.

Apart from the advantages and disadvantages, each study result has its weaknesses and limitations. Likewise, the findings of our study were in designing methods and instruments involved. Of course, there are quite many disadvantages; among others, we only rely on current data and limited literature so that the results can be said to be not representative of the overall condition. This may be better in synchronization; in the future, this study can be redesigned with methods and instruments that are even greater in scope-for example, combining both qualitative and quantitative data so that the results can be more significant and reliable

\section{CONCLUSION}

Based on the discussion of this study's findings, this paper has directly confirmed that the future of paper print-based instructional media has begun to be pushed aside by internet-based media and digitization. This is the main point from the studies we conducted on the review of dozens of published journal articles that voiced how education has also innovated and technological innovations in all life areas in this 21st-century era. With the consideration of literature and review of publications, we can say that our hypothesis is accepted that the future of paper print-based educational media will be slowly replaced. This happens in developed countries, but the same story also occurs in developing countries like Indonesia. The Minister of Religion cannot be denied that there are still many schools where print media is still prioritized. This is inseparable from the human resources of education management, who are still inadequate in information and skills to use and see how technology can renovate education to achieve high-quality educational outcomes and meet the times' demands.

\section{REFERENCES}

Aditya, B. R., Nurhas, I., \& Pawlowski, J. (2019). Towards successful implementation of a virtual classroom for vocational higher education in Indonesia. International Workshop on Learning Technology for Education in Cloud, 151-161.

Andoko, B. S. (2010). Migrasi Database dengan Menggunakan SSIS (SQL Server Integration Service) di PT XYZ Indonesia. Jurnal Teknologi Informasi: Teori, Konsep, Dan Implementasi, 1(1), $36-48$.

Aslan. (2019). Peran Pola Asuh Orangtua di Era Digital. Jurnal Studia Insania, 7(1), 20-34. http://dx.doi.org/10.18592/jsi.v7i1.2269

Barthelemy, S., Bethell, M., Christiansen, T., Jarsvall, A., \& Koinis, K. (2011). The future of print media. Retrieved Jan, 4, 2015.

Beniger, J. (2009). The control revolution: Technological and economic origins of the information society. Harvard university press. 
Bennett, W. L., \& Iyengar, S. (2008). A new era of minimal effects? The changing foundations of political communication. Journal of Communication, 58(4), 707-731.

Cameron, N. M. de S. (2017). Will Robots Take Your Job?: A Plea for Consensus. John Wiley \& Sons.

Collins, A., \& Halverson, R. (2018). Rethinking education in the age of technology: The digital revolution and schooling in America. Teachers College Press.

Darmawan, I. G. N. (2020). Quality and Equity of Student Performance in Mathematics in Indonesia, Malaysia, Singapore, Thailand and Vietnam. In Critical Perspectives on Teaching, Learning and Leadership (pp. 123-144). Springer.

Djiwandono, P. (2017). The learning styles of millennial generation in university: A study in Indonesian context. International Journal of Education, 1O(1), 12-19.

Fedorov, A. (2019). Schools And Universities In Audiovisual Media: Experts'opinions. Communication Today, 10(1), 110-123.

Firmstone, J., \& Coleman, S. (2015). Public engagement in local government: The voice and influence of citizens in online communicative spaces. Information, Communication \& Society, 18(6), $680-695$.

Hamid, M. O., \& Jahan, I. (2015). Language, identity, and social divides: Medium of instruction debates in Bangladeshi print media. Comparative Education Review, 59(1), 75-101.

Kilian, T., Hennigs, N., \& Langner, S. (2012). Do Millennials read books or blogs? Introducing a media usage typology of the internet generation. Journal of Consumer Marketing.

Koomey, J., Berard, S., Sanchez, M., \& Wong, H. (2010). Implications of historical trends in the electrical efficiency of computing. IEEE Annals of the History of Computing, 33(3), 46-54.

Kukulska-Hulme, A. (2012). How should the higher education workforce adapt to advancements in technology for teaching and learning? The Internet and Higher Education, 15(4), 247-254.

Mason, S., \& Hajek, J. (2020). Language education and language ideologies in Australian print media. Applied Linguistics, 41(2), 215-233.

McLaughlin, J. E., Wolcott, M. D., Hubbard, D., Umstead, K., \& Rider, T. R. (2019). A qualitative review of the design thinking framework in health professions education. BMC Medical Education, 19(1), 98.

Mondal, S. R. (2020). A systematic study for digital innovation in management education: An integrated approach towards problem-based learning in Vietnam. In Digital innovations for customer engagement, management, and organizational improvement (pp. 104-120). IGI Global.

Nicholas, M., \& Paatsch, L. (2018). Mothers' views on shared reading with their two-year olds using printed and electronic texts: Purpose, confidence and practice. Journal of Early Childhood Literacy, 1468798418792614.

Ninghardjanti, P., Indrawati, C. D., \& Rahmanto, A. (2018). Design of Interactive Digital Books: Learning Facilities Based on the 2017 Revision Spectrum of 2013 Curriculum. International Conference on Teacher Training and Education 2018 (ICTTE 2018), 306-310.

Nossek, H., Adoni, H., \& Nimrod, G. (2015). Media audiences| is print really dying? The state of print media use in Europe. International Journal of Communication, 9, 21.

Putra, P. \& Aslan. (2020). Pengembangan Bahan Ajar Berbasis Imtaq Dan Iptek Di Era Revolusi Industri 4.0 Pada Mata Pelajaran Sains Madrasah Ibtidaiyah. Ta 'Limuna: Jurnal Pendidikan Islam, 9(1), 1-15. https://doi.org/10.32478/talimuna.v9i1.345

Putra, P., Mizani, H., Basir, A., Muflihin, A., \& Aslan, A. (2020). The Relevancy on Education Release Revolution 4.0 in Islamic Basic Education Perspective in Indonesia (An Analysis Study of Paulo Freire's Thought). Test Engineering \& Management, 83, 10256-10263.

Rizk, J. (2018). The 21st century classroom: Technology as a transformative tool in educational routines, rules, and rituals (PhD Dissertation). Hamilton, ON: McMaster University.

Schivinski, B., \& Dabrowski, D. (2016). The effect of social media communication on consumer perceptions of brands. Journal of Marketing Communications, 22(2), 189-214.

Selwyn, N. (2020). Telling tales on technology: Qualitative studies of technology and education. Routledge.

Skinner, B. F. (2016). The technology of teaching. BF Skinner Foundation.

Strouse, G. A., Newland, L. A., \& Mourlam, D. J. (2019). Educational and fun? Parent versus preschooler perceptions and co-use of digital and print media. AERA Open, 5(3), 2332858419861085 . 
Supadiyanto, S. (2013). Implikasi TECMIIN (Technological Mind Iinterpersonal Interconecting) terhadap Peradaban \& Tren Komunikasi Manusia. Interaksi: Jurnal Ilmu Komunikasi, 2(1), 70-77.

Supratman, L. P., \& Wahyudin, A. (2017). Digital media literacy to higher students in Indonesia. International Journal of English Literature and Social Sciences, 2(5), 239217.

Suwana, F. (2017). Empowering Indonesian women through building digital media literacy. Kasetsart Journal of Social Sciences, 38(3), 212-217.

Ternes, K., Iyengar, V., Lavretsky, H., Dawson, W. D., Booi, L., Ibanez, A., Vahia, I., Reynolds III, C., DeKosky, S., \& Cummings, J. (2020). Brain health INnovation Diplomacy: A model binding diverse disciplines to manage the promise and perils of technological innovation. International Psychogeriatrics, 32(8), 955.

Thomas, S., Chie, Q. T., Abraham, M., Jalarajan Raj, S., \& Beh, L.-S. (2014). A qualitative review of literature on peer review of teaching in higher education: An application of the SWOT framework. Review of Educational Research, 84(1), 112-159.

Twenge, J. M., Martin, G. N., \& Spitzberg, B. H. (2019). Trends in US Adolescents' media use, 19762016: The rise of digital media, the decline of TV, and the (near) demise of print. Psychology of Popular Media Culture, 8(4), 329.

Valli, L., \& Buese, D. (2007). The changing roles of teachers in an era of high-stakes accountability. American Educational Research Journal, 44(3), 519-558.

Watson, J., \& Hill, A. (2015). Dictionary of media and communication studies. Bloomsbury Publishing USA.

Williamson, B. (2013). The future of the curriculum: School knowledge in the digital age. The MIT Press. 